\title{
ACQUIRED IMMUNODEFICIENCY SYNDROME (AIDS)- A NEW EPIDEMIC: A REVIEW
}

B)

Sabiha Khan, Mohammed Nasir Khan, Faiz. Falleh \& Abdullah Falleh, M.D.. Ph.D., L.L.B., F.R.C. Palh.

DOI: http://dx.doi.org/10.5915/18-1-11735

Absiracl

Acquired Immunodeficiency Syndrome (AIDS) is a relalively new disease with a defect in cell-mediated immunity resulting in the viclim becoming prey 10 cancers and infections. The retrovirus or human $T$-cell lymphoma virus, HTLV-III, is currenly considered lo be a likely eriologic agent. This disease, which most commonly affects homosexual men. intravenous drug users and Haitians carries a poor prognosis. An allempe is made in this paper to presem a broad review of this entity. The epidemiology of the disease, etiology, signs and symplains, laboralory investigarions and the trearment of the discase are discussed.

With new cases being reporled every day in different parts of the country, there is a mass hysteria about the Acquired Immunodeficiency Syndrome. AIDS. This relatively new medical malady, also called the "gay" plague," has acquired the status of being the most virulent epidemic of the century. The most worrisome aspect of the diseuse is that after three years of intensive investigations, its precise cause remains a matler of speculasion. It is very important for the public to have all known facts aboul this deadly disease, through physicians, so that there is rational thinking about it and cooperation in the areas of early detection or prevention of the disease. This review is based on the s/udy of papers published in 1982-84.1-15

Key Words: AIDS, Acquired Immunodeficiency Syndrome.

Whal is AIDS and Whal Causes l1?

A cuse of AIDS is derined by the Centers for Disease Conirol. CDC, as "a disease, al leasl mojerately prediclive of a dclect in ceil-mediatcd immunily, occuring in a pcrson with no known cause for diminished resistance to that discasc."

AIDS causes a nearly complele breakdown of a person"s rasural immune sy'slcm. When the immune system breaks down, the vicim becomes prey 10 cancers and infections that a normal, healthy individusal would be able to fight ofr. Several opporIugistic infections have been reported in patients with AlOS. Pneumonia, meningilis or encephalitis have been caused by aspergillosis. candidiasis, cryptococosis, cyeumegalovirus (CMV). nocardiosis, pncu-

From; Department of Family Medicine, University of Miami, Miami, Florida; Falreh Farnily Medicine Associates, Plantarion, Florida; Broward Family Practice Associales, Planlation, Florida

Address all correspondence 10:

Dr. Abdullah Falleh, 825I W, Broward

Boulevard, Suite 408, Kingsion Plaza Building,

Plantasion, Florida 33324 mocyiosis, sirongyloidosis, toxoplasmosis, zygonycosis. alypical mycobacleriosis. Esophagitis has been caused by candidiasis. CMV and herpes simplex virus. The JC Virus, a new hunan papovavirus has ciused progressive multifocal leukoencephalopathy. cryprosporidiosis las caused chronic enterocolitis and herpes simplex virus has also caused exiensive mucocurancous diseasu. Several recent papers have discussed in delail the rolc of these in lecting agents, Perhaps the most imporlanl of all the infections is lhe Pneumocystis carinii pneumonia.

A rare iype of malignancy of ten scen in the victims of AIDS is Kaposi's Sarcoma. Several reports havc delailed current oubreaks of Kaposi's Sarcoma in cases of AIDS. Untis recently this was a rare tumor. Severe inmmunologic deficiencies have been detecied in cases of Kaposi's Sarcoma in honiosexual men and Haitans. The inmunologic parameters which have been studied include serum immunoglobulin levels. enumeration of $B$ cell, $T$ cells, $T$-cell subsets and quanlisation of lymphocyle responsiveness to phytohemagglusinin (PHA) and pokeweed mitogen (PWM). Sites of disease include skin, lymph nodes, gastrointestinal Irack, spleen and lung.

CMV antibodies have been found in 80 to 95 per cent of AIDS patients compared with 50 per cent in the general population. CMV has been cultured from 
the urine of homosexual men but hot from the urine of lyclerosexual men. There is also cvidence suggesting that CMV inlections can be transmitled sexually. The Epslein-Barr Virus. EBV, has also been implicared. Antibodics for EBV have boen found in very high concenerarions in a group of AIDS parienis.

The current concent of an eliologic asent is the relrovirus of humar T.cell Iymphoma virus, HTLVIIl. which is an RNA virus with an inherent reverse Iranscriptase. HTLV-IIl has been isolated lirum 18 o! 21 palichs wilh \}ynuphadenopalhy syndrome and 26 of 72 adults and jurcniles with AIDS. It has not been isolated from 115 heallhy heterosexuals. Ancibody to this virus has been isolaled from serum samples of $88 \%$ of AlDS paticnts and $79 \%$ of patients with lymphadenopathy syndrome. Only 1 ol 64 healihy patien(s had this anibody. The antibody appears 10 be direcled agdinst a viral cnvelope prolein. French investigators isolated a virus in the sane family of viruses which may be the identical organism and has been referred (o) as a lymphadenopathy virus (LAV). They have derined a code protein of this agent which can also be usce for serologic evaluation. A third renrovirus isolate has been found in hemophiliacs, referred to as immunodeficiency associated virus (IDAV $V_{2}$. il appears to be quitc similar if nor identical with the other two.

\section{Transmission or AIDS}

Transmission of the disease is probably through sexual contacts (anal, vayinal or oral), blood iranstusions, usc of contaminaled needles (by drug users). intimalt ranily contacls (skin infections), saliva. semen or urine, and possibly transmited by the molher to the faus in lier womb. This patern of transmission paralleds llial of hepalitis B virus infeclion.

\section{Enormily of llic Problem}

The first reports on isolaled cases of AlDS were published by the CDC in the summer of 1979. As of November 26. 1984 physicians and heallh deparlments in the Uniled States had reported 6.993 patients mecting lle surveillance definition for acquired immunudeficiency syndrome. More lhan $86 \%$ of the adult parients with AIDS and $82 \%$ or the pediatric paricnls have been reporled since January 1983. Threc ilsousand inree inundred and rorty-luso $(48 \%)$ of ail reported palients are known to have dicd ( $48 \%$ of the adulis and $69 \%$ of the children), including $73 \%$ of palienls diagnosed before January 1983.

Epidemiologists predict that the chance of survival beyond 5 years will be less than 35 per cent. The gravisy ol thesc prediccions is evident in the fact that before the days ol vaccinalion even small pox killed orily 25 per eens of the victims.

\section{Incubation Pertod}

The incubalion perion for AIDS is thought to be 6 in 8 moniths and possibly as long as 2 years. That incans, a person who has recently been infected with a virus causing AIDS may nol develop symploms for many months and Itus remain in the dark about the existence of lhis ralal disease for up 102 years.

\section{The Mus' Likely Victims}

The analysis of cases in the United States allows identificalion of several groups thal are at increased risk for developing AlDS. The high-risk groups are:

(a) Homosexual men-with multiple sexual parıners

(b) Intravenous drug uscrs

(c) Hailians

(d) Parients with hemophilia

(e) Female parlners of drug users

(I) Womes who are sicady sexual rartners of men with AlDS

(b) Woinen who are sexual parlners of men in high risk groups

(b) Infants born 10 mothers from groups al high-risk for AIDS

(i) Recipients of blood donated inadverlently by viclims of AlUS.

The homosexuals form by far, the largest group, accounling for 71 per cent of all of the 6,993 reporicd cases. The drug abuscrs rank second with 17 per cent of all cases of AIDS. It is a mystery as to why Haitians have einerged as a high-risk group. Five per cent of AIDS cases are Hailian men and women, especially those who came co the U.S. within the past few years. AIDS is the second leading cause of death in hemophiliacs, ranking second to uncontrollable bleeding. Eleven cases of unexplained infections and immune deficicncy have been diagnosed in patienls with hemophilia in recent months. Parients recciving blood or blood product iransfusion have also been know to contraci AIDS. There have been 13 such cases. Instances of AIDS in previously healthy women also have been recorded.

In addition to the patients in the high risk group. Chamberland el at reporled 201 cases of the acquired immunodeficiency syndrome in persons who could not be classified inlo a group identified 10 be al increased risk for this syndrome. Thirly-five had received transfusion of single donor blood components in the $S$ years preceding diagnosis of the syndrome and 30 were sexual parners of persons belonging 10 a high risk group. However, informa. tion was incomplete for most remaining parients, but bccause many of these patients are demographically similar to populations recognized to be at increased risk for the syndrome, previously identified risk factors may have bcen present but not reported for some of thent. Addicionally, a few persons who meal the 
case definition for the syndrome probably had other reasons for the opporiunistic disease and did not have the acquired inmunodeficiency syndrome. The slow emergence of the acquired immunodeficiency syndrome in new populations is consistent with transmission mediated through sexual contact or parental exposure to blood.

\section{Symptoms and signs of AIDS}

The most common symptoms are fatigue (in 70 per cent), fever (in 40 per cent) and night sweats (in 44 per cent). These symptoms persist for weeks or months. Some patients (28 per cent) lose weight. Diarrhea is also a frequent complaint.

In cases of Pneumocystis Carinii pneumonia fever is usually associated with shortness of breath. If the victim has Kaposi's Sarcoma, he may have dark blue or purple-brown plaques or nodules in the skin. Thesc are most commonly seen on lower extremities but may occur on any part of the body. Some patients experience headaches, loss of appetite and difficulty in swallowing and rarely they suffer from seizures and other neurological abnormalities.

A common fealure of the disease is the enlargement of lymph glands in the neck or groins. In about 26 per cemt of the patients, there is also enlargement of liver and the spleen. Fungal infections and thrush are sometimes seen.

In children with immune deficiency the clinical picture consists of anemia (hypochromic mycrocylic). infections. failure 10 thrive, hepatosplenomegaly. recurrent febrile cpisodes, thrush and eczema-like rash.

\section{Prevention and Control of AIDS}

Several organizations such as the National Gay Task Force, the National Hemophilia Foundation, the American Red Cross, the American Association of Blood Banks, and the American Association of Physicians for Hunran Rights have issued statements on prevention and control of A IDS. AJI organizations, physicians, public and the press should share responsibilicy in disseminating available information on AIDS. The following recommendations should be followed by persons or organizations concerned. These will greally help in controlling and preventing AIDS:

1. A person experiencing symploms of AIDS should seek medical advice as soon as possible so that the physician can take a full history, perform a complete examination, carry out laboratory tests, and render appropriate advice.

2. Individuals in high-risk groups should realize that multiple sexual partners tend to increase the probability of developing AIDS.

3. Sexual coneacts with persons known or suspected to have AIDS should be avoided.
4. The high-risk persons should refrain from donating blood and/or plasma.

5. Physicians should adhere strictly to medical indications for transfusions.

6. Blood collection centers should adopt strict screening procedures to eliminale donors with a probability of Iransmitting AIDS.

7. Infants born to mothers from groups al high-risk for AIDS should be carefulfy screened by physicians.

8. Every proven or suspected case of AIDS should be reported to CDC.

9. Additional recommendations made by the CDC. The Public Health Service or the U.S. Deparment of Health and Human Services and the National Hemophilia Foundation should be sought and carefully implemented.

10. Male homosexuals involved in extensive sexual activity should use condoms during sexual aclivity.

\section{Trealmenl}

There is a natural concern in the minds of those who are afflicted and even the ones who are not as to the effectiveness of ireatment. It must be stressed at the outser that the diseasc has been resistant to treatment and response has been poor 10 various aggressive medications.

Most treatments aim at reversing the abnormality of immune deficiency, fighting cancer or fighting the virus.

Dr. Allan L. Goldstcin of the George Wastington University School of Medicine has shown that thymosin, a group of hormones secreted by thymus gland aclivates the immune system. Therefore, it is possible that thymosin can be useful in the treasment of AIDS if it is caused by maliunction of the thymus gland.

Dr. Bihan Salai, aı Sloan Kellering Cancer Center. has tried interferon with good results. He has trcated Kaposi's Sarcoma with this drug. Of the 12 patients who have completed I reatment, 3 have no evidence of cancer and their immune systems has improved. Some cases of Kaposi's Sarcoma have responded to trea1ment with an experimental drug (VP-16-2I3) developed to treal leukemia. Results of responses to Chemotherapy with single agents such as Vimblastine, Actinomycin D., Rozaxone, Bleomycin, Cytoxan, DTIC and combinations of agents Actinomycin $D$ with Vineristine, Actinomyein D with Vincristine and DTIC. Vinblastine with Bleonycin, Methyl CCNU with Adriamycin have been recorded.

A drug called pentamidine, available through CDC, has been tried for Pneumocystis Carinii pneu. monia with good results.

In general, the results of t realments are disappoint. ing. There is no promise of eure on the horizon. The prospcets are well summarized by Dr. Henry Masur of the National Institute of Health who has said, 
"since patients with AIDS are susceptible to such a wide range of devastating infections and neoplasms (growths), real progress in this syndrome will probably be made by elucidaling the mode of transmission of AIDS and the mechanisms of immunosuppression."

\section{What Can a Physician Do For bus Patieat?}

Every physician should familiarize himself with all aspects of AIDS. He should be able to render advice to the patient on symptoms of the disease, prevention of the syndrome and most importantly, conduct an examination 10 identify some of the signs such as enlarged glands, enlarged liver and spleen and skin changes. He should carry out investigations that may throw additional light on the possibility of the existence of this disease. For instance, he could order Anti-HBc test to detect possible AIDS infectivity in blood. This blood test is positive in 90 per cent of the victims of AIDS and in only 5 per cent of the general population. Other investigations may include chest $\mathrm{x}$-ray, biopsy of skin lesions, virologic and fungal studics and immunologic tests. A summary of abnormal laboratory tests is presented in Table 1. The physician should refer the patient to an appropriale place for further investigations if his office is not equipped to carry oul the investigations. A greal deal of compassion will be needed in dealing with the patients of AIDS.

\begin{tabular}{|c|c|}
\hline \multicolumn{2}{|c|}{ ABNORMALLABORATORY TESTS IN AIDS } \\
\hline LABORATORY TEST & RESULT \\
\hline T Helper Celis (T4) & $b \downarrow$ \\
\hline$T 4 / T 8$ Ralio & $\downarrow \downarrow$ \\
\hline Total Cells (TII) & 3 \\
\hline $\lg 0$ & 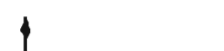 \\
\hline CMV, E.B. and herpes anlibody titer & 1 \\
\hline Hepatitis B corc AB (antj-HBc) & + \\
\hline $\begin{array}{l}\text { Skin rests for PPD, histo, candida, } \\
\text { dermolophylin, mumps }\end{array}$ & $\downarrow t$ \\
\hline $\begin{array}{l}\text { Lymphoblastic transformation } \\
\text { PHA, Con A and PWM }\end{array}$ & $\downarrow \downarrow$ \\
\hline Nacural killer cell cyroloxicity & $\downarrow$ \\
\hline Circulation immune complexes & Normal or \\
\hline Total hemolyric complement activity & 1 \\
\hline
\end{tabular}

\section{Social Impact of the Discase}

The epidemic proportions of the disease, lack of knowledge of its cause, far from satisfactory treatments, poor prognosis and high fatality rates have created a disastrous impact on the society:
1. The heallhy populacion is concerned about the spread of the disease.

2. The contacts of the high-risk population are anxious about their involvement.

3. The high-risk groups are developing a psychiatric syndrome of anxiety, depression. loss of selfrespect and fear of contracting the disease.

4. Those who are known 10 suffer from the disease are fearlul of death. They are carrying the social stigma of the disease. They are becoming "unlouchables." They are raising eries of discrimination - social discrimination, job discrimination, medical discrimination. The fright is so overwhelroing that the AIDS victims are shunned by their communities, their fellow workers, and sometimes by their friends and families. In New York, even funeral directors are wary of handling AIDS victims. The homosexual community and the Haitians are outraged at such reactions.

\section{Conclusions}

HTLV-IIILAV is currently the besl viral candidate for the etiologic agent of AIDS, and proof of this causal role will probably come from either disease eradication by a vaccine or production of the disease by the agent in an animal model. Also we should soon be hearing about one or more sensitive and specific diagnastic tests for detecting the presence of the infection through the measurement of specific antibody to the virus and serum or the idenritication of a product associated with virus replication. Such a test will allow us 10 determine when the infection-as opposed to the disease occurs and in parlicular to prevent transmission by contaminated blood or blood products. Furthermore, specific public health and personal measures needed 10 diminish the spread of AIDS from direct human contacl will become obvious with this information. Even those serious efforts to treal chronic viral infection are only just beginning, there are several obvious lessons we can learn from whas has already been done. For example, the first need is for accurate data on natural history. If this virus is like most persistent viruses, there is a stage in the normal host that is associased with either minor or asympromatic disease, and this probably consuitutes the bulk of infections. II is even possible that an infection by other agents acts as a cofactor or that multiple human retroviral infections are required for the development of the severest form of the infection, full blown AIDS. For example, in recipients of organ allografts, in whom most of the same infectious and neoplastic complications occur, although less frequently. cytomegalovirus infections have a cofactor role with the clinically required immunosuppressant drugs in causing enhanced susceptibility. Of course, the ulsimate test of ow 
understanding will be whether we can concrol this agent in human beings. Undoubtedly, the benefits will not come soon enough for all but an apparacus capable of altacking this problem rationally is currently in place. Furthermore, previous experience with persistent viral infections suggests that there is much work ahead. Experienced investigators know that the fact that vaccines can be produced does not mean that the whole problem can be deah with quickly. Instead, we will most probably need a combination of effecrive diagnostic cools. vaccines, and anriviral or immunoenhancing therapy (or bolh) to provide discase control for all who are al risk.

\section{REFERENCES}

I. Drew Wl., Minlx L. Miner RC. Sands M, and Ketlerer B: Prevalenee ol Cylomegalovirus Infection in Homosexunl Men. J. of Inrectious Diseases 143: 2, 1981.

2. Follansber SF, Busch DF, Worsy CB, Coleman DL. Gulled J. Aurigemma CiP, Ross $T$. Hadicy $K W$, and Drew Wh: Ars Oulbreak or Pneunocysis carinis Pneumonia in Homosesual Meis, Ann of InI Meu 96; 1. 1982.

3. Fricdman-Kien AE, Lubenstein L.I, Rubinsicin $P$. Buinoovici-Klcin E. Marmor N', Sıahs R. Spigland I, Kin KS, and Zolla-Pazner S: Disseminaced Kaposi's Sarcoma in Homosexual Men. Ann of Int Hed 96: 1, 1982.

4. CDC-Updarc: Acquired mumunodeficiancy Syndrome. J.A.M.A. 252: 3155-3356. 1984.

5. Oleske JN, Minucfor AB: Acquired Immune Defichency Syndrome in Childrin. Pediaric Infectious Disease 2:2, 1983.

6. Overby LR: AIDS: A New and Deadly Disease. Hepatits Forsm. Abbon Laboralories Diagnosics Division, March. 1983.

7. Physisam Wushingron Keport, Volume 6. No 12, Jurk 1483.

8. Pitchenik AE, Fikdil MA, Diekinxon CM, Becker DiW. Fournier AM, O.Conncll NT, Collon RM, and Spinci TJ: Oppar-
Mnivic lulections and Kaposi's Sarcoma Among Hailinns: Evdlence of a New Acquired Inmunodeticiency Slale. Ami of lin Mad 93:3. 1983.

9. Puon MC, Landay A. Prasthofer EF. and Sragno S: Acyured Immunodeficiency Syndrame wrth Pnuemocystis carimin Pneumonia and Mycobacierium asium-instacellulare Infection IIs i Prievinusly" Healthy Palicnl with Classic Hemopitilia. Ann or In! Afid 98:3. 9983.

10. Kubinstien A, Sickin'k M, Gupua A, Bernstein L. Klein N. fubinsicim $\mathrm{E}$, Spigland I, Fruchicr L. Lilman $\mathrm{N}, \mathrm{Les} H$ and Hollander $M$ : Acquired Immunodeficiency Syndrome. 3.A.M.A. 244:17, 1983 .

11. Small CB, Kltin RS, Friedland GH, Moll B. Emesen EE. and Sprigland I: Communily-Acquircd Opportunistic Infections and Defective Ceilular Immunity in Heterosexual Drug Abusers and Honosexual Men. Amerian J of Med 6-4: March 198.!

12. Sonnabend J, Wilkin SS, and Purbiln DT: Acquired Immumadeficiency Syndrenuc, Oppartunistic Immunodeficiency

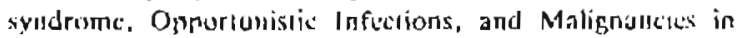
Mile Honosexuals. J.A.M.A. 249: 17, 1984.

13. Seahl KL. Fricdmun-kicn $A$, Dubin R, Marmor M, nud Colia-Pussur S: Imnunulugic Abnormalisics in Humurexual Mtn: Retalismship 10 Kanusi's Sarcoms. American J of Mod 73: Aus, 1982.

Id. Viera J, Frank E, Spira TJ, and Laldesman SH: Acyuired Iommene Deficienty in Haifians: Opporsmistic Infirions in Previously Heakhy Haitian Immierans. Nite Ens: J Mud 308:3, 1983.

15 Volberding P. Conani MA, Sincket RB. Lewis 8J: Chemolherany in Advanced Kaposi's Sarcoma: Implicalions for Curreni Casen in Homosexual Men. American $J$ of Med 74: April 1983.

16. The inferion Reporter, Volume 1. Na. 2, February, 1984.

17. Chamberlafd ASE, Casmo KC. Haverkos HWe al: Acquired smmunudefietency Syndrome in the United States: An Aratysis of Cases Ouisiste High-Incidente Groups. Ann il Ini Med lor: 617623, 1984.

18. Brodur $S$, Gallo RC: A Pahopenic Rorruvirus (HILV-III) l.inked in AIDS. New Eng J Mcd 311:1242. 1984.

14. Merign TC: What are we going wa do aboul AlOS asd HCI V.IIM.AV indocishs? NGW Elty J Mod 311:1311. 1484. 